\title{
The indigenous and invasive fishes in two main reservoirs in the southwestern Anatolia (Aydin)
}

\author{
Hüseyin Sasi1 and Selcuk Berber2 \\ 1. Department of Freshwater Biology, Fisheries Faculty, Mugla Sitki Kocman University, Kotekli, Mugla, Turkey, \\ +90.2522111894; Fax: +90.252 2111887; hsasi@mu.edu.tr \\ 2. Department of Freshwater Biology, Fisheries Faculty, Canakkale Onsekizmart University, Canakkale, Turkey
}

Received 27-VII-2012 Corrected 9-XI-2012 Accepted 12-XII-2012

\begin{abstract}
Buyuk Menderes River basin, located in the Southern part of Turkey, has two significant dam lakes. Threats include pollution (industrial and agricultural activities), overfishing, habitat degradation and drought. This study was carried out to determine the native and non-native fish fauna in Kemer and Topcam dams lakes in the Buyuk Menderes River. Specimens were caught by scoop and gill nets between April 2007 and February 2008. Kemer is inhabited by Cyprinus carpio, Squalius cephalus, Barbus plebejus escherichi, Silurus glanis Acanthobrama mirabilis and Chondrostoma maendrense. In Topcam Dam has Cyprinus carpio, Squalius cephalus, Acanthobrama mirabilis and Capoeta bergamae. Both had the invasive Lepomis gibbosus, Pseudorasbora parva and Carassius gibelio. Acanthobrama mirabilis is endangered fishes and Chondrostoma maendrense and Capoeta bergamae are two of the vulnerable species.
\end{abstract}

\section{KEY WORDS}

Kemer, Topcam Dam Lake, native, exotic fish, Anatolia.

\section{RESUMEN}

La cuenca del Río Buyuk Menderes, situado en la parte sur de Turquía, cuenta con dos embalses importantes. En la cuenca, hay muchas amenazas causadas por la contaminación (actividades industriales y agrícolas), la presión pesquera, la degradación del hábitat, captación de agua y barreras, así como una precipitación baja. Este estudio fue realizado para determinar la fauna de peces nativos y no nativos en los lagos de los embalses Kemer y Topcam en el río Buyuk Menderes de la parte sur de Turquía, suponiendo que los peces indígenas afectados están siendo afectados por los peces exóticos. Ambos lagos de las represas tienen pesca y acuacultura. En este estudio, las muestras fueron capturadas con red de mano y redes trasmallo durante los meses abril de 2007 y febrero de 2008. Como resultado del estudio, se identificó que en el embalse Kemer se cuenta con especies de Cyprinus carpio, Squalius cephalus, Barbus plebejus escherichi, Silurus glanis Acanthobrama mirabilis y Chondrostoma maendrense. En el embalse Topcam, Cyprinus carpio, Squalius cephalus, Acanthobrama mirabilis y Capoeta bergamae. En ambos embalses, se identificaron los peces invasores Lepomis gibbosus, Pseudorasbora parva y Carassius gibelio. Acanthobrama mirabilis es uno de los peces amenazados; Chondrostoma maendrense y Capoeta bergamae son dos de los peces vulnerables que están presentes en el río Buyuk Menderes.

\section{PALABRAS CLAVE}

Kemer, represa Topcam, nativo, peces exóticos, Anatolia.
The invasion of non-native fish species is accelerated by human activities in last few decades all over the word. Importation of the non-native species in many places causes to the extinction of native fish, also homogenizes biodiversity at regional and global levels (McKinney, 2001).

In Anatolia, biodiversity freshwater fish is rich with 213 species owing to its zoogeographic location. Also, it is known that 30 fish species are endemic in Turkey (Balik, 1995; Geldiay \& Balik, 1999). The taxonomic and ecological survey in the South-Western and Mediterranean region of Turkey including some rivers in Aydin, Mugla, Denizli and Antalya (Kucuk \& Ikiz, 2004; Yılmaz et al., 2006; Yegen et al., 2008). In addition, a large number of invasion fish and translocated fish species were introduced from Anatolia 
and Thrace in the last two decades (Sasi \& Balik, 2003; Ekmekci \& Kirankaya, 2006). Also, there are many studies about fish fauna taxonomy, distribution, biological and reproduction characters of freshwater fish in natural habitats of Russia and surrounding areas (Berg, 1964).

A total of 25 exotic fish species have been introduced in Turkey as fry or fingerlings for different purposes over the last decade as compiled by Innal and Erk'akan (2006). The impact of most introductions is completely unknown, even though such introductions are governed by DSI (State Water Works), Ministry of Agriculture and Rural Affairs and Ministry of Environment and Forestry.

Some exotic and indigenous species from one drainage system to another are assessed for enhancement of many natural water around the world. Also, the introduction of exotic fish was made by restocking activities in reservoirs accidentally or deliberately. One of global problems is the biodiversity of freshwater systems has deteriorated as a result of human activities.

Topcam and Kemer Dam Lakes were established in the Buyuk Menderes River basin, where they occur in Aydın province, the South Aegean Region. Both dam lakes have very important ecological terrains.

The main purpose of the study is to determine indigenous and invasion fishes from two main dam lakes in Southern Anatolia. Many freshwater ecosystems have been facing up many problems resulting from introduction of non-native species for management strategies.

\section{METHODOLOGY}

Buyuk Menderes River is a major water source in the region and flows into Aegean Sea. The study was carried out to determine the indigenous and invasion fishes in two reservoirs in the Southern Anatolia and how the exotic fish affects the native fishes.

The study was conducted in two man-made dam lakes of Topcam and Kemer Dam Lakes in the Southwestern part of Turkey from April 2007 to February 2008.

The Kemer Dam Lake is located in Bozdogan province of Aydın. The lake was built up in 1958 for irrigation, flood control and power production. The lake fed by Akcay, Degirmendere, Sarhosdere, Bagderesi and Keklit Streams and precipitations. The Reservoir is located in the Buyuk Menderes River basin in South-western part of Turkey. Akcay goes out from the lake. In normally water level, the lake area is $14,75 \mathrm{~km}^{2}$.

Topcam Dam Lake, fed by Madran Stream and precipitation, was constructed in 1984 for irrigation and flood prevention. The Reservoir is located in the Buyuk Menderes River basin. The water level of both reservoirs decreased during late spring and summer times every year because of irrigational uses. When the rainfalls begin in winter, water level increases again.

Specimens were captured using gill nets $(18-45 \mathrm{~mm}$ mesh sizes) and scoop net. The fish were fixed with $4 \%$ formaldehyde solution in the field, and then carried to laboratory. We measured fork length (FL), total weight (WT) and recorded the sex.

\section{RESULTS}

As a result of the study, 14 species belonging to 6 families (Cyprinidae, Centrarchidae, Siluridae, Poeciliidae, Anguillidae, Salmonidae) were identified. The fish found are as follows;

Phylum: Chordata

Subphylum: Vertebrata

Classis: Osteichthyes

Ordo: Cypriniformes

Familia: Cyprinidae Cyprinus carpio (Linnaeus, 1758)

Squalius cephalus (Linnaeus, 1758)

Barbus plebejus Bonaparte, 1839

Acanthobrama mirabilis Ladiges, 1960

Chondrostoma maendrense Elvira, 1987

Capoeta bergamae Karaman, 1969

Capoeta tinca (Heckel, 1843)

Carassius gibelio (Bloch, 1782)

Pseudorasbora parva (Temminck \& Schelegel, 1846)

Ordo: Perciformes

Familia: Centrarchidae

Lepomis gibbosus (Linnaeus, 1758)

Ordo: Siluriformes

Familia: Siluridae

Silurus glanis (Linnaeus, 1758)

Ordo: Cyprinodontiformes

Familia: Poeciliidae

Gambusia affinis (Baird \& Girard, 1853)

Ordo: Anguilliformes

Familia: Anguillidae

Anguilla anguilla (Linnaeus, 1758)

Ordo: Salmoniformes

Familia: Salmonidae

Oncorhynchus mykiss (Walbaum, 1792)

Lepomis gibbosus is known as pumpkinseed. This specie is benthopelagic. Although this fish is not commercial, it could be important for aquarium fisheries. Pseudorasbora 
parva, commonly known as stone moroko, is a small cyprinid. Both species were determined in Topcam and Kemer Dam Lakes. Both species are non-native fish and they come from Thrace Region (Turkey) while the economical fish, common carp (Cyprinus carpio) is restocked.

Carassius gibelio is actually a non-native fish and was recklessly transferred from Thrace Region in a similar way. The species occur in both dam reservoirs and its importance rests on its local commerciality. We found the largest specimen to be $800 \mathrm{~g}$.

Acanthobrama mirabilis lives in Buyuk Menderes River basin in South-western Anatolia. This species is extinct from Bafa Lake (Sari \& Bilecenoglu, 2002). This species, whose population has reduced and vulnerable were found in Topcam Dam Lake.

Chondrostoma meandrense occur in the Buyuk Menderes River basin, and its population has been reduced and, so it must be protected. It is listed a vulnerable species (Conservation status, VU) in the International Red List (IUCN) (Crivelli, 2005). We found this species in Kemer Dam Lake.

Capoeta bergamae is known Transcaucasian barb that it is benthopelagic and potamodromous. This species is distributed in the South-west of Anatolia from Izmir to Dalaman River. It is important commercial for fisheries. This fish is vulnerable species (IUCN) (Crivelli, 2005).

Gambusia affinis, known as mosquito fish, was found with high population in Topcam Dam lake, which has a slow flowing water. It is ecologically important to struggle against carries for mosquitoes and commercial for aquarium fisheries.

Cyprinus carpio is one of the first transplanted species into resoirvoirs in Turkey. Transplantation initiated in the 1960's by the Ministry of Agriculture and Rural Affairs (DSI). Common carp populations remain successful productive for fisheries in many waters. This species, both varieties mirror and scaled fish, has been restocked in Topcam and Kemer Dam Lakes by DSI.

Silurus glanis, wels catfish, found in Kemer Dam Lake and the species has attracted interest for a cage aquaculture in this Reservoir. Wels catfish is commercial for fisheries, aquaculture and gamefish. It is demersal and non-migratory.

Oncorhynchus mykiss, rainbow trout, is evolving for aquaculture activities in both reservoirs. This species escaped from fish farms. Kemer Dam lake has more immense aquaculture facilities than Topcam Dam lake, because it has suitable water temparature in summer season.

Introduction of exotic fish, both C. gibelio and L. gibbosus, has increased "richness" (Table 1). Moreover, some indigenous fish density, such as C. capoeta and S. cephalus in both reservoirs, reach to a high population, because lentic waters have more stable condition with which the fishes evolve.

In Anatolia, the Southwestern Region has a warm climate. In the study areas, the average mean water temperatures of Topcam and Kemer Dam Lakes were, 19,74 and $15,80^{\circ} \mathrm{C}$, respectively in the period research was conducted.

TABLE 1

The occurrence of the fish species in Topcam and Kemer Dam Lakes

\begin{tabular}{llcc}
\hline \multicolumn{1}{c}{ Fish species } & \multicolumn{1}{c}{ Status of fishes } & Topcam Dam Lake & Kemer Dam Lake \\
\hline Cyprinus carpio & Translocated & ++ & ++ \\
Carassius gibelio & Exotic & +++ & ++ \\
Capoeta bergamae & Native/Vulnerable & +++ & +++ \\
Capoeta tinca & Native & ++ & ++ \\
Squalius cephalus & Native & +++ & ++ \\
Acanthobrama mirabilis & Native/ Endangered & + & + \\
Chondrostoma meandrense & Native/Vulnerable & - & + \\
Barbus plebejus & Native & - & ++ \\
Pseudorasbora parva & Exotic & ++ & ++ \\
Silurus glanis & Translocated & - & ++ \\
Lepomis gibbosus & Exotic & +++ & ++ \\
Gambussia affinis & Translocated & +++ & - \\
Anguilla anguilla & Native & - & + \\
Oncorynchus mykiss & Translocated & - & + \\
Abundance: $(+++)$ Richness, (++) A few, (+) Rarely, (-) None & &
\end{tabular}


During the study period, the average of dissolved oxygen (D.O) is determined varied from $7,48 \mathrm{mg} / \mathrm{L}$ for Topcam Dam Lake and 7,60mg/L for Kemer Dam Lake. The other means of parameters are $\mathrm{pH} 8,01-8,56$, conductivity $148,90-268,00 \mu \mathrm{mhos} / \mathrm{cm}^{3}$ and $\left(\mathrm{HCO}_{3}\right)=64,10-68,60 \mathrm{mg} / \mathrm{L}$ in Topcam and Kemer Dam lakes, respectively (Table 2).

TABLE 2

The mean of some physico-chemical parameters of Topcam and Kemer Dam Lakes (April, 2007 - February, 2008)

\begin{tabular}{|c|c|c|}
\hline Parameter & $\begin{array}{c}\text { Mean of Topcam } \\
\text { Dam Lake } \\
\text { (Min-Max) }\end{array}$ & $\begin{array}{c}\text { Mean of Kemer } \\
\text { Dam Lake } \\
\text { (Min-Max) }\end{array}$ \\
\hline Temperature $\left({ }^{\circ} \mathrm{C}\right)$ & $\begin{array}{c}19,74 \\
(8,30-29,20)\end{array}$ & $\begin{array}{c}15,80 \\
(9,80-23,50)\end{array}$ \\
\hline $\mathrm{pH}$ & $8,01(7,20-8,84)$ & $8,56(7,86-8,96)$ \\
\hline $\mathrm{DO}(\mathrm{mg} / \mathrm{L})$ & $7,48(5,10-10,40)$ & $7,60(6,10-9,90)$ \\
\hline Conductivity $(\mu S)$ & $\begin{array}{c}148,90 \\
(118,0-176,8)\end{array}$ & $\begin{array}{c}268,00 \\
(156,0-20,6)\end{array}$ \\
\hline$\left(\mathrm{HCO}_{3}\right)=(\mathrm{mg} / \mathrm{L})$ & $\begin{array}{c}64,10 \\
(42,30-97,60)\end{array}$ & $\begin{array}{c}68,60 \\
(32,10-99,10)\end{array}$ \\
\hline
\end{tabular}

\section{DISCUSSION}

The objective of the study was to provide native and invasion fish species and fisheries activities in two main dam lakes in the Buyuk Menderes River basin in South-Western part of Turkey. In this study, a total of 14 fish species were found. Of the found fish species, two are endemic and three are exotic in Buyuk Menderes basin.

Zoogeographic location of Turkey has a highly rich in biodiversity of freshwater fish with 213 species (Geldiay \& Balik, 1999), of which 30 are endemic (Balik, 1995; Crivelli, 2005). Moreover, a large number of introduced and translocated species, 25 fish in total, are reported (Innal \& Erk'akan, 2006).

We found invasion fishes in both reservoirs as follows; Prussian carp (C. gibelio), pumpkinseed (L. gibbosus) and stone moroko (P. parva). Many introduction fish invasion have apparently increased in the last two decades as $C$. gibelio, L. gibbosus and P. parva were previously recorded in Thrace (Sasi \& Balik, 2003; Innal \& Erk'akan, 2006). While transporting the economically important fish as common carp (Cyprinus carpio) juveniles, Prussian carp was also transferred arbitrarily to the Southwestern part of Turkey. It appears that Prussian carp have spread toward
Anatolian inland waters. Throughout much of its range, Prussian carp is an ecological species and has a little commercial importance (Sasi, 2008). The invasion fish of L. gibbosus, P. parva and C. gibelio prevailed in both reservoirs to cause drawback economical and environmental impacts.

Prussian carp is the most common in East Asia and Siberia, introduced and widely distributed throughout Europe (Kottelat, 1997). The wild form of the gibel carp is known in Eastern Europe, the Black Sea basin, the Caspian Sea basin, the Azov Sea basin and Thrace Region of Turkey (Welcomme, 1988).

A review of the ichthyofauna of $P$. parva in the lowland rivers is found in many regions and river systems of Europe, including Danube delta and Anatolia (Ekmekci \& Kirankaya, 2006).

Many riverine species populations as Squalius cephalus, Capoeta bergamae have evolved with a high rate in Topcam and Kemer Dam Lakes, because riverine species can live under more harsh and variable conditions. However, when a dam lake was built, many of the riverine species do not adapt and die, while some move out of the area. For example, eel, Anguilla anguilla, has barely appeared in Kemer reservoir, but none in Topcam reservoir. Also, the downstream areas of the dam lakes have a negative impact. The floodplain is cut off from its connection in river, and the dam prevents the upward movement of migratory fish, as is the case with usually big dams.

Following reference with Geldiay and Balik (1999), Kosswig (1951) and Tortonese (1955), the origins of fish species in the area are noted as follows; Mediterranean; Anguilla anguilla, Europe-Asia; Squalius cephalus, Petroleuciscus smyrnaeus, Silurus glanis, South-East Asia; Barbus plebejus, Cyprinus carpio, Carassius gibelio, Pseudorasbora parva, Near East-Asia; Capoeta bergamae, Africa; Tilapia zillii, America; Gambusia affinis and Lepomis gibbosus. Yilmaz et al. (2006) was given Petroleuciscus smyrnaeus from Akcay River in the Buyuk Menderes basin, also we didn't find this species during the study period.

Many threats of freshwater fisheries underline gross changes in the habitat or community structure, e.g. pollution, flow regulation, loss or change of aquatic habitat, over-exploitation and identifies of exotic species (Cowx, 2002). These reasons have all contributed through the critical situation facing many freshwater fish species in Southwestern Anatolia as Acanthobrama mirabilis and Chondrostoma meandrense.

Acanthobrama mirabilis is known from Buyuk Menderes and threatened due to water abstraction. This species population was reduced from Bafa Lake as connection of which was banned by Buyuk Menderes River with an artificial barrier (Bogutskaya, 1997; Sari \& Bilecenoglu, 2002). 
Also, the population characteristics for Capoeta bergamae and Carassius gibelio in Kemer Reservoir is maintained (Ozcan, 2007; Ozcan \& Balik, 2009).

The transfer and introduction of some invasive and translocated fish (Carassius gibelio, Lepomis gibbosus and Pseudorasbora parva) had a considerable negative influence on other economically important species (Cyprinus carpio Barbus plebejus, Capoeta bergamae, Squalius cephalus) and native species (Acanthobrama mirabilis, Chondrostoma meandrense) due to the competition for food resources. The adverse ecological impact of these exotic fishes in several countries is reported, especially because of the fact that L. gibbosus and P. parva feed on small fishes and fish eggs.

\section{REFERENCES}

Balik, S. (1995). Freshwater fishes of Anatolia. Biological Conservation $72,213-223$.

Berg, L.S. (1964). Freshwater Fishes of the U.S.S.R. and Adjacent Countries. Academy of Sciences of the U.S.S.R. Zoological Institute, Guide to the Fauna of the U.S.S.R. Volume: II, Number: 29, Fourth edition, Translated from Russian, Israel Program for Scientific Translations. U.S.S.R. Zoological Institute: Russia.

Bogutskaya, N.G. (1997). Contribution to the knowledge of leuciscine fishes of Asia Minor. Part 2. An annotated checklist of leuciscine fishes (Leuciscinae, Cyprinidae) of Turkey with descriptions of a new species and two new subspecies. Mitteilungen Hamburgisches Zoologisches Museum und Institut 94, 161-186.

Cowx, I.G. (2002). Analysis of threats to freshwater fish conservation: past and present challenges. Conservation of Freshwater Fishes: Options for the Future, 201-220.

Crivelli, A.J. (2005). The freshwater fish endemic to the Mediterranean region. An action plan for their conservation. Tour du Valat Publication 171.

Ekmekci, G. \& Kırankaya, G. (2006). Distribution of an Invasion Fish Species. Pseudorasbora parva in Turkey. Turkey Jounal of Zoology 30, 329-334.

Geldiay, R. \& Balık, S. (1999). Turkiye Tatlisu Baliklari. Ege Üniversitesi Fen Fakültesi Kitaplar Serisi 97, 519.
Innal \& Erk'akan. (2006). Effects of Exotic and Translocated fish species in the Inland waters of Turkey. Reviews on Fish Biology and Fisheries 16, 39-50.

Kucuk, F. \& Ikiz, R. (2004). Fish Fauna of Streams Discharging to Antalya Bay. E.U. Journal of Fisheries and Aquatic Sciences 4, 287-294.

Kosswig, C. (1951). The zoogeography of Near and Middle East. Journal of Turk Bıology 1, 217-227.

Kottelat, M. (1997). European freshwater fishes. Biologia 52 5,1-271.

McKinney, M.L. (2001). Effect of population, area, and time on non-native plant and fish diversity in the United States. Biological Conservation 100, 243-252.

Ozcan, G. (2007). Distribution of Non-Indigenous Fish Species, Prussian Carp, C. gibelio (Bloch, 1782) in the Turkish Freshwater Systems. Pakistan Journal of Biological Sciences 10, 23, 4241-4245.

Ozcan, G. \& Balık, S. (2009). Some biological parameters of the bergamae barb, Capoeta bergamae Karaman, 1969 (Cyprinidae), in Kemer reservoir (Aydin, Turkey). North-Western Journal of Zoology 5-2, 242-250.

Sari, H.M. \& Bilecenoglu, M., 2002. Threatened fishes of the world: Acanthobrama mirabilis Ladiges, 1960 (Cyprinidae). Environmental Biology of Fishes 65, 318.

Sasi, H. \& Balık, S. (2003). The Distribution of Three Exotic Fishes in Anatolia. Turkey Journal of Zoology 87, 34-38.

Sasi, H. (2008). The Length and Weight Relations of Some Reproduction Characteristics of Prussian carp, Carassius gibelio (Bloch, 1782) in the South Aegean Region (AydınTurkey). Turkish Journal of Fisheries and Aquatic Sciences 8, 87-92.

Tortonese, E. (1955). The Trouts of Asiatic Turkey. Istanbul Univ., Hydrobiology Research Institute 2, 1-25.

Welcomme, R.L. (1988). International introductions of inland aquatic species. FAO Fisheries Technical Paper 294, 318.

Yegen, V., Balik, S., Bilecenoglu, E., Sari, H. M., Uysal R. \& Yagci, A. (2008). Fish fauna of Streams and theirs distributions in Denizli province. Journal of Fisheries Sciences 2, 301-311.

Yılmaz, F., Barlas, M., Yorulmaz, B. \& Ozdemir, N. (2006). A Taxonomical Study on the Inland Water Fishes of Mugla. Ege University Journal of Fisheries \& Aquatic Sciences 1, 27-30. 